\title{
Long-term Use of Methadone for Refractory Cancer Pain: A Cohort Follow-up Study
}

Audrey Fawoubo, M.D. ${ }^{1}$, Colombe Tricou M.D. ${ }^{1}$, Violaine Bordier, M.D. ${ }^{1}$, Guillaume Economos, M.D. ${ }^{1,2}$, Elise Perceau-Chambard, M.D. ${ }^{\text {, }}$ Murielle Ruer, RN. ${ }^{1}$, Sophie Munier M.D. ${ }^{1}$ Marilene Filbet, Assoc. Prof. ${ }^{1}$

1: Hospices Civils de Lyon, Palliative Care, 365 Chemin du Grand Revoyet, 69130 Pierre Bénite, France

2: King's College London, Cicely Saunders Institute, Bessemer Rd, SE5 9 JP, London, United-Kingdom

\section{Background:}

Up to $15 \%$ of cancer patients experience intractable cancer-related pain. $\mathrm{D}$-methadone is a mu-opioid receptor agonist (antinociceptive activity) as well as an anti-N-Methyl-D-Aspartate receptor (anti-NMDA).

The anti-NMDA activity offers the theoretical possibility to mitigate neuropathic pain.

Aim:

$\checkmark$ To explore the effectiveness and security in time of methadone in mitigating cancer-related refractory pain as a third-line painkiller.

\section{Methods:}

- Mono-centric French prospective cohort study from Sept. 2014 to Dec. 2017.

- Inclusion criteria: cancer patients experiencing refractory cancer-related pain.

- Exclusion criteria : long QT interval condition.

- Substitution process: Opioid daily doses were converted into equivalent oralmorphine (EOM), used ratios were:

$$
\begin{gathered}
<100 \mathrm{mg} \rightarrow 1 / 5-1 / 3 \\
100-300 \mathrm{mg} \rightarrow 1 / 5-1 / 10 \\
300-600 \mathrm{mg} \rightarrow 1 / 10-1 / 15 \\
600-1000 \mathrm{mg} \rightarrow 1 / 15 \\
>1000 \mathrm{mg} \rightarrow 1 / 20
\end{gathered}
$$

Daily doses were administered three times a day for $48 \mathrm{~h}$ then twice a day Additional doses were $1 / 6$ of daily doses.

Study schema:

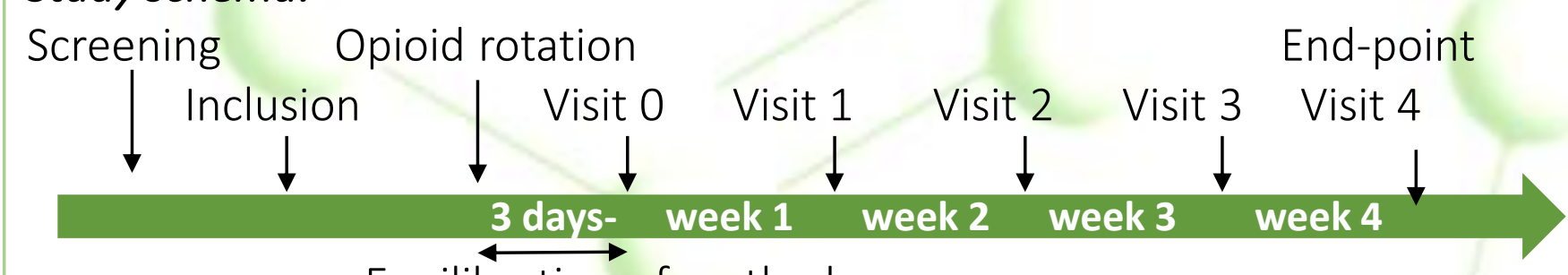

Equilibration of methadone

\section{Collected data:}

- $\quad$ Pain components (VAS, Neuropathic pain score inventory)

- Methadone's doses

- $\quad$ Cancer-related symptoms (Edmonton Symptom Assessment Scale: ESAS)

- $\quad$ Anxiety and depression (hospital anxiety and depression scale: HADS)

\begin{tabular}{|c|c|c|c|}
\hline Characteristics & $N(\%)$ & & \\
\hline $\begin{array}{l}\text { Gender ratio } \\
\text { female/male (F/M) }\end{array}$ & $0.4(11 / 27)$ & \multirow{3}{*}{$\begin{array}{l}\text { Previous oncologic } \\
\text { treatments } \\
\text { Chemotherapy } \\
\text { Radiotherapy } \\
\text { Surgery }\end{array}$} & \multirow{3}{*}{$\begin{array}{l}34(89) \\
25(66) \\
19(50)\end{array}$} \\
\hline Mean age in years & 61 [48-74] & & \\
\hline $\begin{array}{l}\text { Localisation of cancer } \\
\text { Head and neck }\end{array}$ & $9(24)$ & & \\
\hline Lung & $6(16)$ & \multicolumn{2}{|l|}{ ECOG PS } \\
\hline Pancreas & $5(13)$ & 1 & $2(5)$ \\
\hline Breast & $3(8)$ & 2 & $24(65)$ \\
\hline Gynaecologic & $1(3)$ & 3 & $6(16)$ \\
\hline Gastrointestinal & $6(16)$ & 4 & $5(14)$ \\
\hline Urologic & $3(8)$ & DN4 $>4$ at day 0 & $13(34)$ \\
\hline Blood & $3(8)$ & Mean daily EOM (mg) & $422[104-740]$ \\
\hline Other & $2(5)$ & \multirow{2}{*}{$\begin{array}{l}\text { Co-analgesic } \\
\text { Acetaminophen }\end{array}$} & \multirow{4}{*}{$\begin{array}{l}27(71) \\
13(34)\end{array}$} \\
\hline Stage of the disease & & & \\
\hline Metastatic & $28(74)$ & Antineuropathic & \\
\hline Recurrent & $2(5)$ & drug & \\
\hline Locally advanced & $6(16)$ & \multirow{2}{*}{$\begin{array}{l}\text { Mean daily dose of } \\
\text { methadone at day } 0 \\
\text { (mg) }\end{array}$} & $32.5[19.5-$ \\
\hline Local & $2(5)$ & & 45.5] \\
\hline
\end{tabular}

- $\quad$ Quality of life (EORTC QLQ-C30)

- $\quad$ Side-effects (Likert-scales)

Statistics were performed using the R-stat software version 3.3.3.

The significance level was defined as $\alpha=0.05$.

\section{Results :}

Characteristics of included patients are summarised in table 1. Overall, they were mostly males (71\%), aged 61 years old (48-74) and suffering head and neck (24\%), and lung cancers (16\%). Most patients suffered from advanced cancer (90\%). The average daily EOM before rotation was $422 \mathrm{mg}$ (1041200). After rotation, the average daily dose of methadone was $32.5 \mathrm{mg}$.

\section{Primary outcomes:}

Pain intensity tended to decreased, from day 14 (Table 2).

Intensity of components of neuropathic pain tends to decrease (at least 2 points) for: $53 \%$ for compression, $29 \%$ for burning, $24 \%$ for allodynia, $24 \%$ for paroxysmal pain and $12 \%$ for paraesthesia (Figure 1).

Daily doses of methadone remained stable during the follow up with an average dose of $39 \mathrm{mg}$ at day $28(\mathrm{p}=0.54)$.

\begin{tabular}{lllll}
\hline & VAS $\leq \mathbf{4 0}$ & $\mathbf{4 0}<$ VAS $\leq \mathbf{7 0}$ & VAS > 70 & p- value \\
\hline D0 & $26.3 \%(10)$ & $55.3 \%(21)$ & $18.4 \%(7)$ & \\
D7 & $48.4 \%(15)$ & $32.3 \%(10)$ & $19.4 \%(6)$ & 0.12 \\
D14 & $50 \%(12)$ & $46 \%(11)$ & $4 \%(1)$ & 0.08 \\
D21 & $55 \%(11)$ & $35 \%(7)$ & $10 \%(2)$ & 0.09 \\
D28 & $50 \%(8)$ & $44 \%(7)$ & $6 \%(1)$ & 0.19 \\
\hline
\end{tabular}

Table 2: Visual analogic scale for pain by intensity of pain during follow-up.

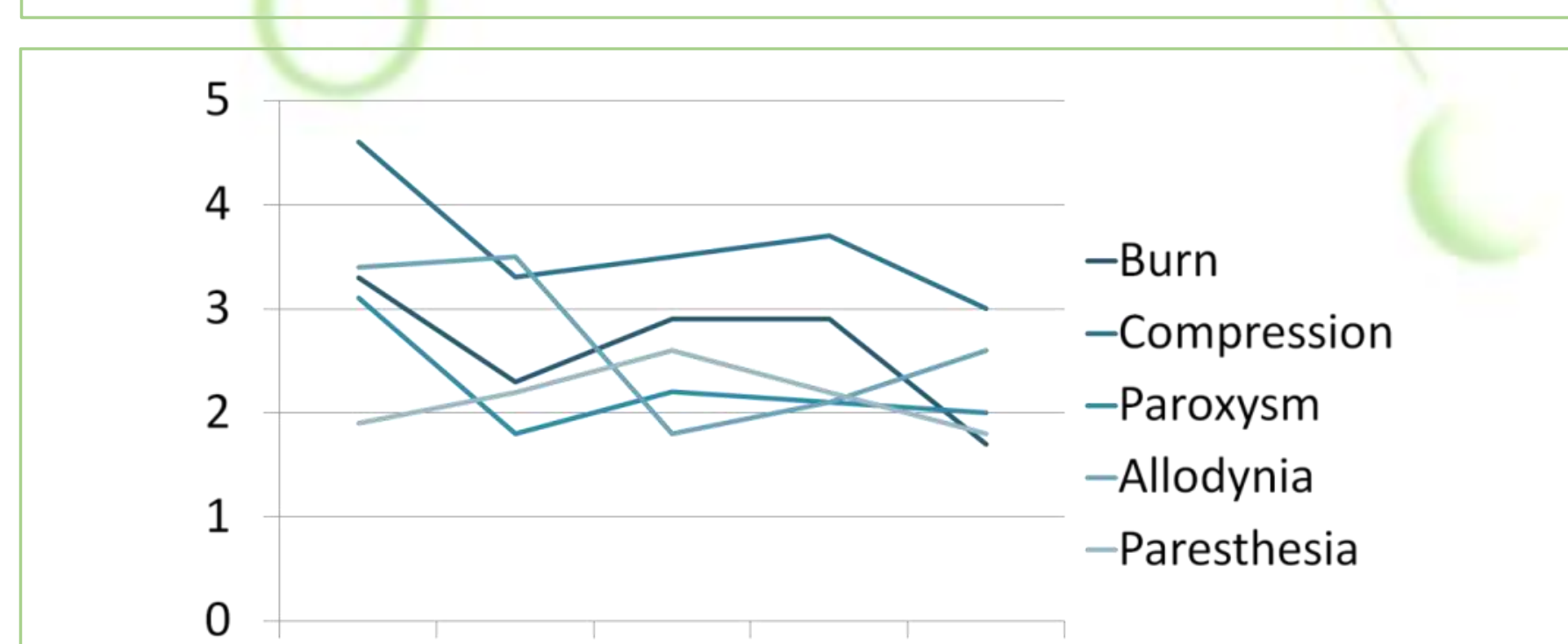

Day 0 Day 7 Day 14 Day 21 Day 28

Figure 1 : NPSI subscales ratings during follow-up.

\section{Side effects:}

- $\quad$ Confusion was significantly higher at day $7(p=0.04)$.

- $\quad$ Severe drowsiness tended to be higher at day $28(p=0.08)$.

- $\quad$ Sweating was significantly higher at week $1(p=0.004)$.

- Myoclonus, dizziness, fatigue, lack of appetite, breathlessness, constipation and emesis remained stable.

- Overdose signs remained stable during the follow-up ( $p=0.7)$.

\section{Anxiety and depression:}

- A drop of $22 \%$ of patients reporting mild to severe anxiety has been found on the ESAS subscale at day $28(p=0.006)$.

- No improvement in depression (HADS and ESAS subscales) nor in anxiety (HADS subscale) has been found.

Quality of life: No improvement has been shown, nor with the ESAS subscale "wellbeing" ( $p=0.24)$, nor with the EORTC QLQ-C30 $(p=0.9)$.

\section{Conclusions:}

Our results supports a delayed effectiveness of methadone in alleviating the neuropathic component of cancer-related refractory pain. 